\title{
The Application of Cultural Model for Literacy through Legends to Enhance Speaking Ability of Second Semester English Students of Sriwijaya University
}

Fitri Suci Puspita Sari, Rita Inderawati, Zuraida

Sriwijaya University, Palembang, South Sumatera

(uchie 212@yahoo.com )
( ritarudysaid@yahoo.com)
(zuraida.blani@gmail.com )

\begin{abstract}
This study aimed to find out whether or not there was any significant difference in speaking ability of the students who were taught by implementing CML (Cultural Model for Literacy) through legends and those who were not. The sample was 41 undergraduate students enrolled in English course at FKIP of Sriwijaya University which were taken by purposive sampling method from 85 total of population. This study used one of the quasi-experimental designs that were pretest posttest non equivalent control group or comparison group design. The students were divided into two groups - the experimental and control groups. The experimental group was required to do some phases in treatment of 16 meetings including pre-test and posttest in accordance with introducing new model of teaching speaking that was CML through legends. The data were obtained through speaking test by measuring their oral interpretations to know the students speaking ability. The test was administered twice as pre-test and post-test in both groups. The results indicated that there were any significant differences at level 0.05 level found in the data which were analyzed by using paired sample t-test $(t=12.156>t$-table $=2.080)$ and independent sample $t$-test $(t=3.252, p<0.05)$. The results also showed that $C M L$ through legends could enhance students' speaking ability of the second semester English students of Sriwijaya University.
\end{abstract}

Key words: CML (Cultural Model for Literacy), Legends, Teaching Speaking, Oral Interpretation

\section{Council for Innovative Research}

Peer Review Research Publishing System

\section{Journal: Journal of Social Sciences Research}

Vol .5, No.2

jssreditor.cir@gmail.com

www.jssronline.com 


\section{INTRODUCTION}

Brown (2007, p. 136) states English is not only as a tool for being learned but also as a tool for international communication. It directs for English teachers should design four skills of English that are listening, speaking, reading and writing in the form of instruction optimally especially speaking because in the real situation a spoken language will much be used.

Liao (2009) says that speaking skill is the one which is in the real-life situation will be measured most. According to Kayi (2006) speaking is an important part of second language teaching and learning. Speaking can express the ideas, thoughts and opinions through oral communication. Furthermore, he also states that the improvement of students' communication skill is one of the goals in teaching speaking that on its process, students could follow the social and culture role in every single interaction.

In English Education Study Program of Sriwijaya University Palembang, students still get speaking course in order to sharpen their speaking ability. They use their speaking ability to provide their oral performance like presentation, discussion and other instructions in teaching and learning process. However, they still get some difficulties in mastering speaking skill. Aprilia (2012) assumes Indonesian people are not able in speaking English fluently and accurately because they have not been prepared for spontaneous communication. Based on that study, teachers should prioritize two important goals of speaking that are accurate (clear, articulate, grammatically, and phonologically correct) and fluent (flowing and natural). These features of language are used by members of a speech community for purposes of communication, the exchange of thought (Brown, 1987, p. 14).

Based on the interview done with some of students in the second semester English Education Study Program of Sriwijaya University Palembang, they were being taught by monotonous way in their speaking class such as they were given some topics then they would talk as monologue as they know about that topic, so they got some performance factors in speaking like being nervous and confused of what they would talk about. So, they already have had a good basic speaking ability and there were many ways to make them speak accurately and fluently. One of the ways is teachers give the approach of teaching and learning strategies that closely related to students' daily life like their culture to be a topic spoken. Students are taught literature only in high schools and language literature lesson in Indonesia (Inderawati, 2013). Speaking culture can be as natural as expected if students get their interests in learning literature itself. According to Hirsch cited in Syamshayooadeh (2011, pp. 58-59) teaching more cultural content in the schools is an attractive idea. Here, cultural model for literacy comes up in relation with English speaking teaching; it involves culture, language and technology in the form of instructional design. Literacy combines language with its four skills and technology involved, so cultural model for literacy is expected to make the students become addicted with literary works' issue throughout learning English as spoken language. Hirsch (2001) also claims that literacy is more than just mechanics of reading, literacy means understanding what people read and to understand it, people have to have appropriate background knowledge. Toward speaking English class in the second semester English students at Faculty of Teacher Training and Education of Sriwijaya University, it is crucial part when they are asked to speak or respond after reading the literary works as an appreciation form of the literary works then they will do such a discussion.

Inderawati (2007) assumes that since the Information and Communications Technology is widespread as the core of learning process nowadays, students are familiar with the media to browse learning materials and to chat with others in all over the world. In responding and appreciating literary works, the role of technology has a big part on meeting students' learning style. According to Dudeney and Hockly $(2007$, p. 7$)$ the use of technology in the classroom is becoming increasingly important, the students are using technology more and more. Social media like Facebook, as media of students doing a chat and creating an interaction among their real-life friends or others, is being used as media of learning today. Similarly, Inderawati (2011) explains that the existing phenomenon of students using Facebook in Indonesia is they actively share comment, make a friend and chat with friends or families. It is supported also by the findings of the study conducted by Inderawati (2011), she concluded that Facebook is suitable media for students' appreciation toward literary works and reader response strategy is applicable in describing short stories, novels, local literature etc.

One of literary works that can be appreciated by students is legend. According to Oxford Advanced Learner's Dictionary (Hornby, 2005, p. 878), a legend is a story from ancient times about people and events, which may or may not be true. However, legend is the past events happened; a legend that purely comes from Indonesia will help the students know more about the history of their country. Students will be asked to find out those legends and appreciate them. In appreciating literary works, there are some experts have conducted their studies on dealing with this, one of them by applying two strategic responses; they are Reader Response Strategy and Visual Symbol Response. Based on the study conducted by Inderawati et.al (2013) the implementation of Reader Response Strategy and Visual Symbol Response in Literary Appreciation class is the way to improve the students' skill in understanding literary works and in developing their cultural literacy. So they created Cultural Model for Literacy or CML as model of teaching provided that combines Reader Response Strategy, Tableau as Visual symbol and Facebook as medium for commenting their speaking performance. In this case, this model has been developed to meet teaching speaking class. From the Model, In the process of teaching and learning, students will actively use reader response strategy in appreciating the legend as one of literary works and also making a tableau as visual symbol response of the legend chosen by their small group. Tableau is an art performance of literacy that forces the students to do some discussions and to make a guess toward the frozen scene made by their friends. Here, literary works will be seen its contribution to the improvement of students' speaking ability. Then, CML is aimed to make the students interest in appreciating literary works by speaking in English.

From the explanation above, the experimental research would be conducted entitled "The Application of Cultural Model for Literacy to Enhance Speaking Ability through Legends to the Second Semester English Students at Sriwijaya University Palembang". The writer wants to find out whether or not there is a significant difference in speaking ability between students who are taught by using CML through legends and those who are not. This research will be conducted in the second semester English Students at English Language Study Program of Sriwijaya University Palembang. 


\section{METHOD}

In this study, an experimental method used to present the data. The data have been got from the research that was done. The design which used in this experiment was the quasi-experimental design. Creswell (2012) states that quasiexperimental research use non-random assignment from an adequate experimental research or not control conditions within a group thoroughly. One of the designs of quasi-experimental was used, that was non-equivalent group pretestposttest control group or comparison group design (McMillan \& Schumacher, 2010, p.278).

The population of this study was the students enrolled in Speaking I course both Palembang and Indralaya class with a total number of 85 English students of FKIP Sriwijaya University Palembang in academic year 2012/2013. In this study, purposive sampling method technique was used. The sample was the IIA classes both Palembang and Indralaya because both classes were taught by the same lecturer and needed to be improved on their speaking ability.

This study used one instrument, which was the test. The test would be administered twice as a pretest that were given before the treatment and a post test that would be given after the treatment. The test was an oral test in which each student was assigned to speak spontaneously and interpret orally about the legend as the topic given. To get the reliability and the validity, the test must be appropriate to students' level of competence of English by judging from some experts. Inter-rater reliability was used to find out the reliability of the test. To find out correlation coefficient, Pearson Product Moment was used. The calculation will be done by using SPSS 21 (Statistical Package Social Science). Wallen and Fraenkel (1991, p.99) argue the reliability coefficient is considered strong and can be used for the test, if the value is higher than 0,70 . In this study, the statistical analysis showed that the reliability coefficient is 0,719 and it was considered reliable and strong, it could be used for the test of this study either.

To analyze the data collected from the groups, paired sample t-test was used to know the score within each groups and also used independent sample t-test to know whether or not there was a difference performance of the dependent variable, the students' speaking ability, between two groups involved in this study and how significant the difference was. All the performances were measured by speaking rubric and were calculated by SPSS 21.

\section{FINDINGS AND DISCUSSION}

\section{Findinds}

The findings of the study were presented in two main points: (1) the result of pre-test and post test of the experimental group and (2) the result of pre-test and post test of the control group.

In scoring students' pre-test and posttest in both experimental and control group, the writer was helped by the raters. There were two raters in this study, one is a lecturer of English Education Study Program of Sriwijaya University and the other rater is English instructor of Language Institute of Sriwijaya University. A number of the students in the experimental group were 22 students, and a number of the students in the control group were 19 students. Since the scores were got from two raters, the scores were calculated and divided into two.

\section{The Result of the pretest and Posttest in the Experimental Group}

The number of the students of the experimental group was 22 students. The lowest score in pretest was 42 , the highest score was 78 , and the mean score was 56.18 . In the post test, the lowest score was 53 , the highest score was 89 , and the mean score was 70.73 .

The result of pre-test and post test was divided into five categories based on English Department Handbook of FKIP of Sriwijaya University in academic year 2009/2010, they were: failed, poor, average, good, and excellent. In pre-test of the experimental group, no student $(0 \%)$ was in very poor category, 10 students $(45.5 \%)$ were in poor category, 10 students $(45.5 \%)$ were in average category, 2 students $(9 \%)$ were in good category, and no student $(0 \%)$ was in excellent category. While in the post test, no student $(0 \%)$ was in very poor category, one student $(4 \%)$ was in poor category, 12 students $(55 \%)$ were in average category, 7 students $(32 \%)$ were in good category, and 2 students $(9 \%)$ were in excellent category. Table 10 shows the score distribution of experimental group.

Table 1

The Score Distribution in Experimental Group

\begin{tabular}{|c|c|c|c|c|c|}
\hline \multirow{2}{*}{ Score Interval } & \multirow{2}{*}{ Category } & \multicolumn{2}{|c|}{ Pretest } & \multicolumn{2}{c|}{ Posttest } \\
\cline { 3 - 6 } & & Frequency & Percentage & Frequency & Percentage \\
\hline $86-100$ & Excellent & 0 & $0 \%$ & 2 & $9 \%$ \\
\hline $71-85$ & Good & 2 & $9 \%$ & 7 & $32 \%$ \\
\hline $56-70$ & Average & 10 & $45.5 \%$ & 12 & $55 \%$ \\
\hline $41-55$ & Poor & 10 & $45.5 \%$ & 1 & $4 \%$ \\
\hline$\leq 40$ & Very poor & 0 & $0 \%$ & 0 & $0 \%$ \\
\hline
\end{tabular}

\section{The Results of the Pre-test and Post Test of the Control Group}

The number of the students of the control group was 19 students. The lowest score in pretest was 31 , the highest score was 83 , and the mean score was 51.32 . In the post test, the lowest score was 42 , the highest score was 83 , and the mean score was 58.95 . 
In pre-test of the control group, 4 students (21\%) were in very poor category, 7 students (37\%) were in poor category, 7 students $(37 \%)$ were in average category, one student $(5 \%)$ was in good category, and no student $(0 \%)$ was in excellent category. While in the post test, no student $(0 \%)$ was in very poor category, 7 students $(37 \%)$ were in poor category, 7 students $(37 \%)$ were in average category, 5 students $(26 \%)$ were in good category, and no student $(0 \%)$ was in excellent category. Table 11 presents the score distribution of the control group.

Table 2

The Score Distribution in Control Group

\begin{tabular}{|c|c|c|c|c|c|}
\hline \multirow{2}{*}{ Score Interval } & \multirow{2}{*}{ Category } & \multicolumn{2}{|c|}{ Pretest } & \multicolumn{2}{c|}{ Posttest } \\
\cline { 3 - 6 } & & Frequency & Percentage & Frequency & Percentage \\
\hline $86-100$ & Excellent & 0 & $0 \%$ & 0 & $0 \%$ \\
\hline $71-85$ & Good & 1 & $5 \%$ & 5 & $5 \%$ \\
\hline $56-70$ & Average & 7 & $7 \%$ & 7 & $7 \%$ \\
\hline $41-55$ & Poor & 7 & $7 \%$ & 7 & $7 \%$ \\
\hline$\leq 40$ & Very poor & 4 & $4 \%$ & 0 & $0 \%$ \\
\hline
\end{tabular}

\section{The Statistical Analyses}

In order to verify the hypotheses proposed, the statistical analyses were applied. In this study, the results of the pre-test and post test of both the experimental and control group were analyzed by using paired sample t-test in SPSS 21 and independent sample t-test.

\section{The Statistical Analysis of the Experimental and the Control Groups by using Paired Sample T-test}

The statistical analysis between the pre-test and post test of the experimental group by using paired sample t-test showed that the mean score difference of pre-test and post test in experimental group was 14.545. The standard deviation was 5.612 , with standard error 1.197, the t-obtained (12.156) was higher than the critical value of the t-table (2.080), and the significant level of $p$ was below 0.05 in two tailed testing $(0.00<0.05)$. Therefore, the null hypothesis $(\mathrm{H} 0)$ was rejected and the research hypothesis $(\mathrm{H} 1)$ was accepted. It means that there was a significant difference in speaking ability of the experimental group after they were taught by using CML through legends.

The result of paired t-test in control group showed that the mean difference of pre-test and posttest in control group was 7.632. Standard deviation was 9.001, the standard error mean was 2.065 , the t-obtained (3.696) was higher than the critical value of the t-table (2.101), and the significant level of $p$ was below 0.05 in two tailed testing $(0.002<0.05)$. It means that there was a significant difference in speaking ability in control group. Table 12 presents the summary of statistical analysis by using paired sample t-test on both experimental and control groups.

Table 3

The Summary of Statistical Analyses of the Experimental and Control Groups by Using Paired Sample t-test

\begin{tabular}{|c|c|c|c|c|c|c|}
\hline \multirow[t]{2}{*}{ Score Interval } & \multicolumn{3}{|c|}{ Experimental Group } & \multicolumn{3}{|c|}{ Control Group } \\
\hline & Pretest & Posttest & different & Pretest & Posttest & different \\
\hline Mean & 56.18 & 70.73 & 14.545 & 51.32 & 58.95 & 7.632 \\
\hline Standard Deviation & 10.079 & 9.775 & 5.612 & 12.230 & 13.356 & 9.001 \\
\hline Standard Error & 2.149 & 2.084 & 1.197 & 2.806 & 3.064 & 2.065 \\
\hline $\begin{array}{c}\text { t obtain } \\
\text { df }\end{array}$ & \multirow{2}{*}{\multicolumn{3}{|c|}{$\begin{array}{c}12.156 \\
21 \\
0.000\end{array}$}} & \multirow{2}{*}{\multicolumn{3}{|c|}{$\begin{array}{c}3.696 \\
18 \\
0.002\end{array}$}} \\
\hline sig. (2 tailed) & & & & & & \\
\hline
\end{tabular}

\section{The Difference Analysis of the Result of the Post-Test in the Experimental and the Control Group}

To find out whether or not there was any significant difference in students' speaking ability between experimental and control group, the writer compared the result of post test in the experimental group with the result of the post test in the control group by using independent sample t-test.

The results of independent sample t-test show that the mean difference was 11.780 , standard error difference 3.622, and t-obtained was 3.252. At the significant level of $p<0.025$ in two tailed testing with df-39, the critical value of $t$ table was 2.023. It showed that t-obtained was higher than critical value of t-table. It was $3.252>2.023$. The null hypothesis $(\mathrm{H} 0)$ was rejected and the research hypothesis $(\mathrm{H} 1)$ was accepted. It means there was a significant different in speaking ability between who were taught by $\mathrm{CML}$ through legends and students who were not taught by $\mathrm{CML}$ through legends. 
Table 4

The Summary of the Statistical Analysis of the Experimental and the Control Group by Using Independent Sample t-test

\begin{tabular}{|l|l|}
\hline Score Interval & Experimental Group \\
& Control Group \\
\hline Mean & 1.662 \\
Standard error difference & 11.780 \\
t-obtained & 3.622 \\
t-table & 3.252 \\
p-output $(p<)$ & 2.023 \\
\hline $95 \%$ confidence interval of the difference & 0.002 \\
\hline & Lower $: 4.453$ \\
\hline
\end{tabular}

\section{Discussion}

Based on the findings above, some interpretations were made. Before giving treatment, pre-test was given to the students both experimental and control groups. When CML through legends were introduced, the students were involved in learning speaking. Beside the legends were being their materials in speaking class, the writer made it easy to be topic spoken by recognizing CML to the speaking class. The students who were reluctant to speak at beginning of the experiment, at the end most of them felt easy to speak. The result of this study is in accordance with the idea proposed by Sari and Inderawati (2014) assume that in bridging culture and language to technology used toward teaching and learning process, cultural literacy model is effective and feasible for the improvement of four language skills. It is supported also by Khameis (2006, p. 112) who states "to motivate students in EFL contexts, teachers should include many activities and strategies that attract students' attention and make them interested in the lesson". The application of CML as whole package of media and approach is good for English teachers to teach English and they can vary the way of their teaching and learning activity.

The students who were taught by implementing CML through legends in their speaking class had better score in giving the interpretation toward the legends than those who were not. Appreciating legends orally was a practice activity in English language teaching especially speaking. By using CML, they seemed to be more active in delivering their ideas, thought for guessing and knowledge in responding literary works. The enhancement of their speaking ability also seen from the results of post test from experimental group.

Eventually, the difference between the results of the post-test in the experimental group and control group was analyzed by using the independent t-test. Based on the calculation (see Appendix M), by using SPSS 21, a computer program, the value of $t$-obtained was 3.252. At the significant level $p<0.025$ in two tailed testing with $\mathrm{df}=39$, the critical value of t-table was 2.023. Since the value of t-obtained was higher than t-table, the null hypothesis $(\mathrm{H} 0)$ was rejected and the research hypothesis $(\mathrm{H} 1)$ was accepted. From the calculation, it can be drawn that there was a significant difference on the post-test scores of the students in the experimental group and those students in control group. This can prove that CML though legends in speaking class was able to enhance the students' speaking ability.

From the result above, it is stated that the application of CML in teaching speaking through legends could make the students interested in learning English especially speaking and could enhance their speaking ability. During the experiment, the writer observed that the students were involved actively in teaching and learning process. This situation happened because speaking class was taught in different way from their teacher did. By implementing and applying this Model, it is not only built up the students' willingness in speaking English but also gave them much fun in teaching and learning activities. Finally the CML through legends can be used as one of the Model in enhancing the students' speaking ability in university level.

\section{CONCLUSIONS AND SUGGESTIONS}

Based on the findings of the study and the interpretations discussed in the previous chapter, it could be proven by analyzing the students' pretest and posttest score of the experimental group by using paired sample t-test and analyzing the students post test scores of the experimental group and control group using independent sample t-test. From the calculation, the null hypothesis $(\mathrm{H} 0)$ was rejected and research hypothesis $(\mathrm{H} 1)$ was accepted. It can be concluded that there was significant difference in speaking ability after the experimental group was taught by using CML through legends and there was significant difference in speaking ability between students who were taught by using CML through legends and those who were not. In brief, CML through legends can be used as an effective model to enhance speaking ability of second semester English students of FKIP Sriwijaya University.

Some suggestions were drawn that from the conclusion above can be seen that CML can be used as efforts in enhancing students' speaking ability. For the English teachers, in teaching ELT, they should find out the most appropriate teaching medias/methods/materials or models and use them in order to bring fun and enjoyable teaching and learning process to the classroom and to create comfort zone in helping the students learn inside the classroom either. The teachers should prepare a good lesson plan in every meeting and use the best technique for presenting materials as well. The teachers should give the positive responses or appreciate what their students have done, so the students could explore their own ideas confidently. And the teacher should also motivate the students to speak because extrinsic motivation could grow the students' bravery and they could share their opinion, ideas and thought in every chance they had to speak. Their motivation and interest are the important parts in meeting the achievement of learning speaking in English. 
Then, as the students in learning ELT, they also give big influences for the success of teaching and learning process. Here are some suggestions for English students; the students should prepare themselves earlier before they are given the materials in order to have some background knowledge for helping them easy to master the materials itself. The students should take the opportunities in expressing the ideas, answering the questions and presenting something in front of the class. And the students should prepare themselves in using English inside and outside of the class or take an English course, it is as their motivation in learning English as their good attitude toward English subject.

Thus, suggestions also given for further research that this study can be used to enhance students' ability in learning English, especially in Speaking. The next researchers should not only investigate more the problems and difficulties in teaching speaking in order to make speaking English as important as other skills but also find out the deep understanding to solve the problems in teaching speaking.

\section{REFERENCES}

[1] Aprilia, F. (2012). Using news video to improve the eighth grade students speaking skill at SMPN 9 Palembang. Unpublished undergraduate's thesis, Sriwijaya University, Palembang.

[2] Brown, H. D. (1987). Principles of language learning and teaching 2nd edition. New Jersey: NJ: Pearson Education, Inc.

[3] Brown, H. D. (2007). Teaching by principles and interactive approach to language pedagogy. San Francisco: Pearson Education Inc.

[4] Creswell, J. W. (2012). Educational research: planning, conducting, and evaluating quantitive and qualitative research. Boston, MA: Pearson Education, ink.

[5] Dudeney G \& Hockly N. (2007). How to teach English with technology. Pearson Education Limited.

[6] Hirsch JR, E. D. (2001). Cultural literacy. Retrieved from http://projec12.fatcow.com/Background/culliter.pdf

[7] Hornby, A. S. (2005). Oxford advanced learner's dictionary of current English (7th Ed.). New York: Oxford University Press.

[8] Inderawati, R. (2007) Web-Based Literature: Displaying Students' Response to Short Story. In: The 55th Teflin International Conference. Teflin International. ISBN 978-979-17336-0-1. Retrived from

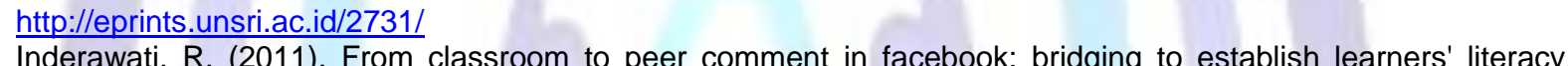

[9] Inderawati, R. (2011). From classroom to peer comment in

[10] Inderawati, R. (2011). The Application of reader response approach and the use of Facebook as a medium to appreciate literary works.

[11] Inderawati, R., Sofendi., \& Zuraida (2013). Strategi Respons Pembaca dan Respons Simbol Visual dalam matakuliah Literary Appreciation untuk pengembangan budaya literasi mahasiswa Pendidikan Bahasa Inggris FKIP Universitas Sriwijaya. Laporan Penelitian HIBA Dikti SITLITAKNAS. Jakarta.

[12] Inderawati, R. (2013). The application of literature for all and literature across curriculum concept by responding literary works to the enlightenment of character education in Indonesia context. Journal of teaching and education , 2(1).

[13] Kayi, H. (2006). Teaching speaking: Activities to promote speaking in a second language. The Internet TESL Journal, XII(11). Retrieved from http://iteslj.org/techniques/Kayi-TeachingSpeaking.html

[14] Khameis, M. (2006). 'Using creative strategies to promote students' speaking skills.', 109-118. Retrieved from: http://marifa.hct.ac.ae/files/2011/07/Using-Creative-Strategies-to-Promote-Students-Speaking-Skills.pdf Accessed on October $9^{\text {th }} 2013$.

[15] Liao, G. (2009). Improvement of speaking ability through interrelated skills. English Language Teaching, 2(3). pp.11-14.

[16] McMillan, J.H., \& Schumacher, S. (2010). Reseach in education: Evidence-based inquiry (7th ed). New York, NY: Harper Collins Publisher.

[17] Sari, F. S. Puspita. \& Inderawati, R. (2014). The application of cultural literacy model to enhance speaking ability through legends for advance students in ELT classroom. 77(17). pp 80-85 DOI: 10.7763/IPEDR.2014.V77.17. Sriwijaya University, Palembang, South Sumatera, Indonesia. Retrived from http://www.ipedr.com/vol77/017rp019 ICLMC2014 N10039.pdf

[18] Syamshayooadeh, G. (2011). Cultural literacy in new millennium: revisiting E.D Hirsch. International Journal of Humanities and Social Science, 1(8). pp.273-277.

[19] Universitas Sriwijaya. (2010). Buku pedoman fakultas keguruan dan ilmu pendidikan Universitas Sriwijaya tahun akademik 2010/2011. Inderalaya: Unsri.

[20] Wallen, N.E., \& Fraenkel, J.R. (1991). Educational research: A guide to the process. New York, NY: McGraw-Hill, Inc. 


\section{ISSN 2321-1091}

\section{WRITERS' BIOGRAPHICAL STATEMENT}

Fitri Suci Puspita Sari, S.Pd. A private English teacher who has presented in some seminars internationally in

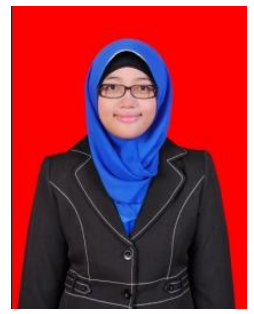

SouthKorea, Palembang, and Jakarta.

Dr. Rita Inderawati, M.Pd., An English Education Study Program lecturer of Sriwijaya University Indonesia, has disseminated her investigations America, Europe, and America. she wrote book entitled Let's Hummanize Ourselves: Educate Brain, Heart, and Action. She was the Best Lecturer of Sriwijaya University and the Best National Researcher of Indonesia in 2013.

Dra. Zuraida, M.Pd. is an English Education Study Program lecturer of Sriwijaya University Indonesia who wrote some articles published internationally and presented those in several outstanding international seminars either. 